\title{
Withholding Irrigation During the Establishment Phase Affected Growth and Physiology of Norway Maple (Acer platanoides) and Linden (Tilia spp.)
}

\author{
Alessio Fini, Francesco Ferrini, Piero Frangi, Gabriele Amoroso, and Riccardo Piatti
}

\begin{abstract}
The aim of this work was to investigate the drought tolerance of different Tilia species and of different cultivars of Acer platanoides grown during the establishment phase, and to evaluate irrigation effect on their growth and physiology. In winter 2004-2005, 168 trees [8-10 cm (3-4 in) circumference] of Tilia platyphyllos, T. cordata, T. $\times$ europaea, T. tomentosa, Acer platanoides 'Summershade', A. platanoides 'Deborah', and A. platanoides 'Emerald Queen' were planted in the field. Eighty-four plants were irrigated with a drip irrigation system (4 1/h) and eighty-four were not. Height, trunk diameter, and shoot elongation were measured at the end of the growing season in 2005, 2006, and 2007. Leaf gas exchange and chlorophyll fluorescence were measured monthly during the 2006 and 2007 growing seasons. Leaf greenness index content was measured in 2006 and 2007. Results indicate that T. tomentosa and T. cordata are more drought tolerant during establishment than T. platyphyllos, while Acer platanoides 'Summershade' is less drought tolerant during establishment than the cultivars 'Emerald Queen' and 'Deborah'.

Key Words. Acer platanoides; Chlorophyll Fluorescence; Drought Avoidance; Leaf Gas Exchange; Tilia spp.; Water Stress.
\end{abstract}

Global environmental conditions have changed during the last century and based on current trends, temperature will rise by about $1^{\circ}-3.5^{\circ} \mathrm{C}\left(1.8^{\circ}-6.3^{\circ} \mathrm{F}\right)$ over the next 70 years, and rainfall will also be affected by a decrease in the frequency and an increase in intensity of rainy events (UNEP/IUC 1999). Water limitation may prove to be a critical constraint to primary productivity of plants under future scenarios of more arid climates due to climate change (Fisher et al. 2001). When referred to shade trees planted in the urban environment and peri-urban forests and recreational areas, plant productivity may correspond with the ability of single plants or plant communities to provide benefits to the inhabitants. Healthy, long-lived trees provide environmental, ecological, economic, social, cultural, and aesthetic benefits to the community (Akbari 2002; Brack 2002; Fini and Ferrini 2007; Nowak et al. 2007; Elmendorf 2008; Escobedo et al. 2008).

Mortality rate in the urban environment is usually very high and ranges from $10 \%$ to $50 \%$ with water stress playing a major role, especially where pavements, soil compaction, and small planting pits prevent infiltration into the root zone (Kaushal and Aussenac 1989; Miller and Miller 1991; Whitlow et al. 1992; Pauleit et al. 2002). This threat is very dangerous in the first years after planting, when mortality can be $50 \%$ in the first year, and up to $34 \%$ in the second (Gilbertson and Bradshaw 1985; Nowak et al. 1990). Irrigation is an important factor to increase plant survival and quality during the establishment phase, but landscape water consumption is highly visible and provides a prime target for water restrictions and subsequent regulation (Scheiber et al. 2007). Despite the need of saving water, water restrictions during landscape establishment can be detrimental to plants which have not had enough time to develop a sufficient root system to compensate for evapotranspirational losses (Montague et al. 2000). One way to increase water efficiency is to irrigate trees until they are fully established and then terminate irrigation unless there are periods of extreme drought. Establishment time can be estimated by comparing leaf gas exchange and growth rates of newly planted stressed (nonirrigated) and unstressed (irrigated) trees (Scheiber et al. 2007).

Another strategy to reduce drought-related transplant losses is to plant species/cultivars that show a certain degree of drought tolerance during the establishment phase. Even within a genus or a species, great differences in water needs for establishment can be found among species/cultivars. A previous work ranked drought tolerance of Fraxinus genotypes on the basis of drought-induced changes in chlorophyll fluorescence, chlorophyll content, and carbon assimilation (Percival et al. 2006).

Few studies have assessed drought tolerance among maples and lindens: most were performed on container-grown plants (Abrams and Kubiske 1990; Zwack et al. 1998; Fini et al. 2008) and none of them addressed drought tolerance during the establishment phase. This is very surprising because maples and lindens are widely-used species for the urban environment in Italy and Europe. Four linden species are commonly used for urban forestry: 1) T. cordata Mill., a native European species widespread from Spain to Northern Greece to Southern Finland which forms climax forest in plain and mountain areas up to 1500 m (0.93 mi) above sea level; 2) T. platyphyllos Scop., a native European species which grows widely from Northern Spain to Caucasus and to Southern Sweden and forms climax forest preferentially in mountain areas, up to $1600 \mathrm{~m}$ (1 mile) above sea level; 3) T. $\times$ europaea (syn. T. $\times$ vulgaris) L. is the natural hybrid between T. cordata and T. platyphyllos; 4) T. tomentosa Moench, a native of Southern Europe and Asia. Norway maple (Acer platanoides L.), and Sycamore maple (Acer pseudoplatanus L.) are the most commonly used maple species in European and Italian towns. A previous study found that A. platanoides is more 
advisable for urban plantings than A. pseudoplatanus (Fini at al. 2008). Several Norway maple cultivars are available for sale, but some such as 'Deborah', 'Emerald Queen', and 'Summershade' are particularly appreciated due to reddish colour of new sprouts, intense green colour of foliage, and heat tolerance, respectively.

The aim of this work was to: 1) investigate the effects of irrigation on growth and physiology of Tilia and Acer platanoides during the establishment phase; 2) evaluate whether differences in drought tolerance during the establishment phase existed within Tilia genus; and 3) evaluate whether differences in drought tolerance during the establishment phase existed among three Acer platanoides cultivars. This information can be useful to urban foresters and arborists in selecting the right species and cultivars within a desired genus.

\section{MATERIALS AND METHODS}

\section{Plant Material and Growing Conditions}

In winter 2004-2005, 168 uniform, 2.5 to $3 \mathrm{~m}$ (8.3 to $9.9 \mathrm{ft}$ ) tall, 3 to $4 \mathrm{~cm}$ (1.2 to $1.6 \mathrm{in})$ diameter [measured at $1.3 \mathrm{~m}(4.3$ $\mathrm{ft}$ ) height], balled and burlapped [size of the root ball was approximately $30 \mathrm{~cm}$ (12 in) in diameter] Tilia platyphyllos, $T$. cordata, T. $\times$ europaea, T. tomentosa, Acer platanoides 'Summershade', A. platanoides 'Deborah', and A. platanoides 'Emerald Queen' were planted in an experimental plot located at the Fondazione Minoprio (Como, Italy, 45 $\left.44^{\prime} \mathrm{N}, 9^{\circ} 04^{\prime} \mathrm{E}\right)$. Mean annual temperature and rainfall of the experimental site, calculated over the last 20 years, are $12.99^{\circ} \mathrm{C}\left(55.38^{\circ} \mathrm{F}\right)$ and $1086 \mathrm{~mm}$ (47.76 in) respectively. Despite of relatively high rainfall, some drought spells are likely to occur in the study site in summer and especially in July, which is the driest and the warmest month.

Trees were planted in a loam soil (51\% sand, $40 \%$ silt, $9 \%$ clay). Planting holes were two times the width of the root-ball and deep enough to position the root flare exactly at the soil level.

Trees of the different species or cultivars were planted in a randomized complete block with three replicates. Each block was made up of four plants per species/cv. and irrigation treatment. All plants were irrigated in 2005 to avoid transplant shock. Starting in 2006, 12 plants per species/cultivar (irrigated; 84 plants for the whole experiment) were irrigated with a drip irrigation system (4 $1 / h)$ in order to maintain constant soil moisture and for 12 plants per species/cv. (nonirrigated) irrigation was withheld throughout the experiment. Irrigation was provided to irrigated plants when evapotranspiration exceeded precipitation, which occurred from May to the end of August 2006, and from June 20 to the end of September 2007 (Figure 1). Effective evapotranspiration (ETE) can be calculated as the product of reference evapotranspiration $\left(\mathrm{ET}_{0}\right)$ and a crop coefficient $(\mathrm{Kc})$. $\mathrm{ET}_{0}$ was measured with a Class A pan evaporimeter. Kc was estimated to be 0.5 to 0.8 for many landscape trees and shrubs including maple and linden (Daugherty 2002; Pardossi et al. 2004). Since we only mattered that irrigated plants experienced no water stress, we overestimated Kc and we considered a $\mathrm{Kc}=1$ for effective evapotranspiration determination as proposed by Pardossi et al. (2004). The difference between rainfall and ETE gave the water balance of the trees. Two irrigation events per week were performed on irrigated plants. Irrigation time was the time needed to recover to 0 (when negative) the difference between rainfall and ETE. Time needed to achieve this goal varied, generally, from 3 (May) to 15 (July) hours per week.

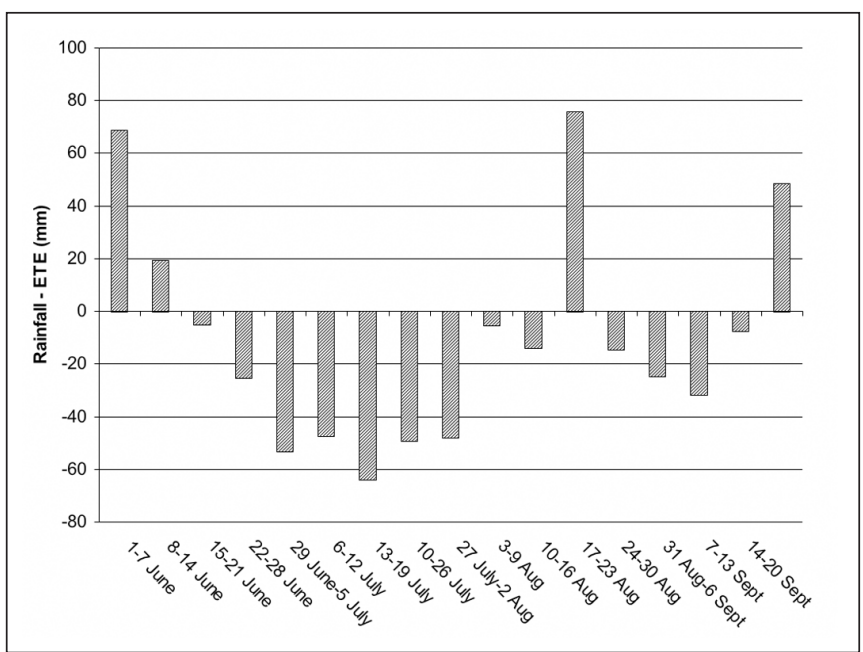

Figure 1. Net balance between rainfall and ETo measured weekly from the first of June to the 20th of September 2007.

\section{Data Collection}

Shoot elongation was measured on 20 randomly chosen shoots on first order lateral branches per plant on two plants per species/cultivar per irrigation treatment per replicate at the end of the growing season in 2006 and 2007. Trunk diameter was measured on all plants at $1.3 \mathrm{~m}(4.3 \mathrm{ft})$ above the root flare.

Leaf gas exchange (net photosynthesis, A, $\mu \mathrm{mol} \mathrm{m} \mathrm{m}^{-2} \mathrm{~s}^{-1}$; transpiration, E, mmol m${ }^{-2} \mathrm{~s}^{-1}$; stomatal conductance, $\mathrm{g}_{\mathrm{s}}, \mathrm{mmol} \mathrm{m}^{-2}$ $\mathrm{s}^{-1}$ ) was measured in 2006 and 2007 from June to September using the CIRAS-2 portable infrared gas analyzer (PP Systems, Hertfordshire, UK). The readings were taken between $8.00 \mathrm{~h}$ and $11.00 \mathrm{~h}$ (maple), and from $14.00 \mathrm{~h}$ to $17.00 \mathrm{~h}$ (linden) on sunny days under fixed $\mathrm{CO}_{2}$ concentration $(360 \mathrm{ppm})$ and saturating irradiance $\left(1300 \mu \mathrm{mol} \mathrm{m} \mathrm{m}^{-2} \mathrm{~s}^{-1}\right.$, provided by a built-in red LED radiation source) on two plants per species/cultivar per irrigation treatment and replicate. Five fully expanded leaves per plant were selected from the outer portion of the crown and at different heights and checked for gas exchange. On July 20 and 27, 2007, leaf gas exchange was measured continuously for the entire day, to assess the daily trend of gas exchange. Data are presented in Tables 5 and 6 as the average between the two sampling dates. Water Use Efficiency (WUE) was calculated as the ratio between $A$ and $E$ as reported in a previous work (Ferrini et al. 2008).

Leaf greenness index was measured with a chlorophyll meter (SPAD-502, Minolta, Sakai, Osaka, Japan) on six leaves per species per treatment and replicate at the end of July in 2006 and at the beginning of September in 2007. A recent work on three tree species shows that SPAD values of leaf chlorophyll content can also be a good indicator of leaf N content and leaf carotenoids (Percival 2008).

Chlorophyll fluorescence was measured on six leaves per species per treatment and replicate with a Plant Efficiency Analyser Chlorophyll Fluorimeter (Handy Pea, Hansatech Ins., King's Lynn, Norfolk, U.K.) in July 2006 and in June, July, and August 2007. Fluorescence values were obtained by placing leaves in darkness for 30 minutes by attaching light-exclusion clips to the leaf surface of whole trees. $\mathrm{F}_{0}$ (minimal fluorescence); Fv/ $\mathrm{Fm}$ and $\mathrm{Fv} / \mathrm{F}_{0}$ were measured after exposing the leaf to a saturating light $\left(3000 \mu \mathrm{mol} \mathrm{m} \mathrm{m}^{-2} \mathrm{~s}^{-1}\right)$. These parameters are reliable 
indicators of the occurrence of environmental stresses, including water stress, on PSII of several woody and herbaceous species (Angelopulos et al.1996; Maxwell and Johnson 2000; Percival and Fraser 2001; Percival et al. 2003, Percival 2005; Lazár 2006; Li et al. 2006; Percival et al. 2006; Yamada et al. 2006). $\mathrm{F}_{0}$, the minimal fluorescence, is a measure of the stability of the light harvesting complex. Fv/Fm is the maximum quantum yield of the PSII. Fv/ $\mathrm{F}_{0}$ is an estimate of the maximum primary yield of photochemistry of PSII. In this study, chlorophyll fluorescence was used to evaluate the occurrence of water stress within the genus Tilia and within the Acer platanoides species. Presence of stress was identified by changes in $\mathrm{F}_{0}$ or decrease in $\mathrm{Fv} / \mathrm{Fm}$ and $\mathrm{Fv} / \mathrm{F}_{0}$ in nonirrigated plants if compared to irrigated plants of the same species/cultivar. Comparison between mean annual leaf gas exchange of irrigated and nonirrigated plants of the same species were measured to identify the drought tolerance strategy adopted by the different species/cultivars.

\section{Statistical Analysis}

All data were subjected to one- or two-way analysis of variance (ANOVA) using SPSS statistical package for Windows (SPSS Inc., Chicago, IL). The two genera were always analyzed independently. Effects of irrigation and species/cultivar were analyzed with a mixed model two-way ANOVA, where irrigation was the fixed effect and species/cultivar the random effect. When no significant interaction between factors was found, differences among species/cultivars within a genus/species were tested with Duncan's multiple range test $(P \leq 0.05$ and $P \leq 0.01)$. Parameters which showed significant interaction between factors were plotted separately in order to compare each level of factor A (species/cultivar) for each level of factor B (irrigation) (Chew 1976). Data on leaf gas exchange were analyzed per single sampling date, merged together, and processed again to obtain an average value on annual basis. Data of daily trend of A and E were analyzed with repeated measures General Linear Model.

\section{RESULTS AND DISCUSSION}

Over the three years of the experiment, no plant died for water stress. Some signs of wilting were found in July 2007 (the driest month in the two years) in nonirrigated T. platyphyllos. By the end of August 2006, nonirrigated Acer platanoides 'Deborah' shed over half of the leaves, while no leaf shedding was observed in irrigated Acer platanoides 'Deborah' and in the other cultivars of Norway maple and linden species.

\section{Effects of Species/Cultivar and Irrigation on Growth, Gas Exchange and Chlorophyll Content} Among the linden species, T. cordata and T. $\times$ europaea had, respectively, the highest shoot growth in 2006 and 2007 (Table 1; Figure 2). In 2006, T. platyphyllos and T. tomentosa were slower growing than both the former species and in 2007 were slower growing than T. $\times$ europaea. Trunk diameter growth had a trend similar to shoot growth in 2006, and no difference among the species appeared in 2007 (data not shown). In 2006, T. cordata had the highest mean annual A and WUE (Table 1). High gas exchange was found also in T. tomentosa, while T. platyphyllos had the lowest gas exchange in both years. In 2006 and 2007, $T$. cordata and T. tomentosa had the highest chlorophyll con- tent respectively, while T. platyphyllos had the lowest. No difference among the species appeared for WUE in 2007. An increase in shoot growth and leaf gas exchange between 2006 and 2007 was observed for T. × europaea, which in 2006 had lower A, WUE, and chlorophyll content especially when compared to T. cordata and T. tomentosa, while it ranked very high in 2007.

Irrigation increased shoot growth and transpiration in both years (Table 1). Net photosynthesis was increased by irrigation only in 2006. WUE and chlorophyll content were unaffected by irrigation. Significant interaction between factors was found for shoot extension in 2006, and for E in 2006 and 2007 (Figure 2). In 2006, shoot growth was increased by irrigation in all species but $T$. $\times$ europaea In 2006, T. cordata had the highest $\mathrm{E}$ both in non irrigated and irrigated environments.

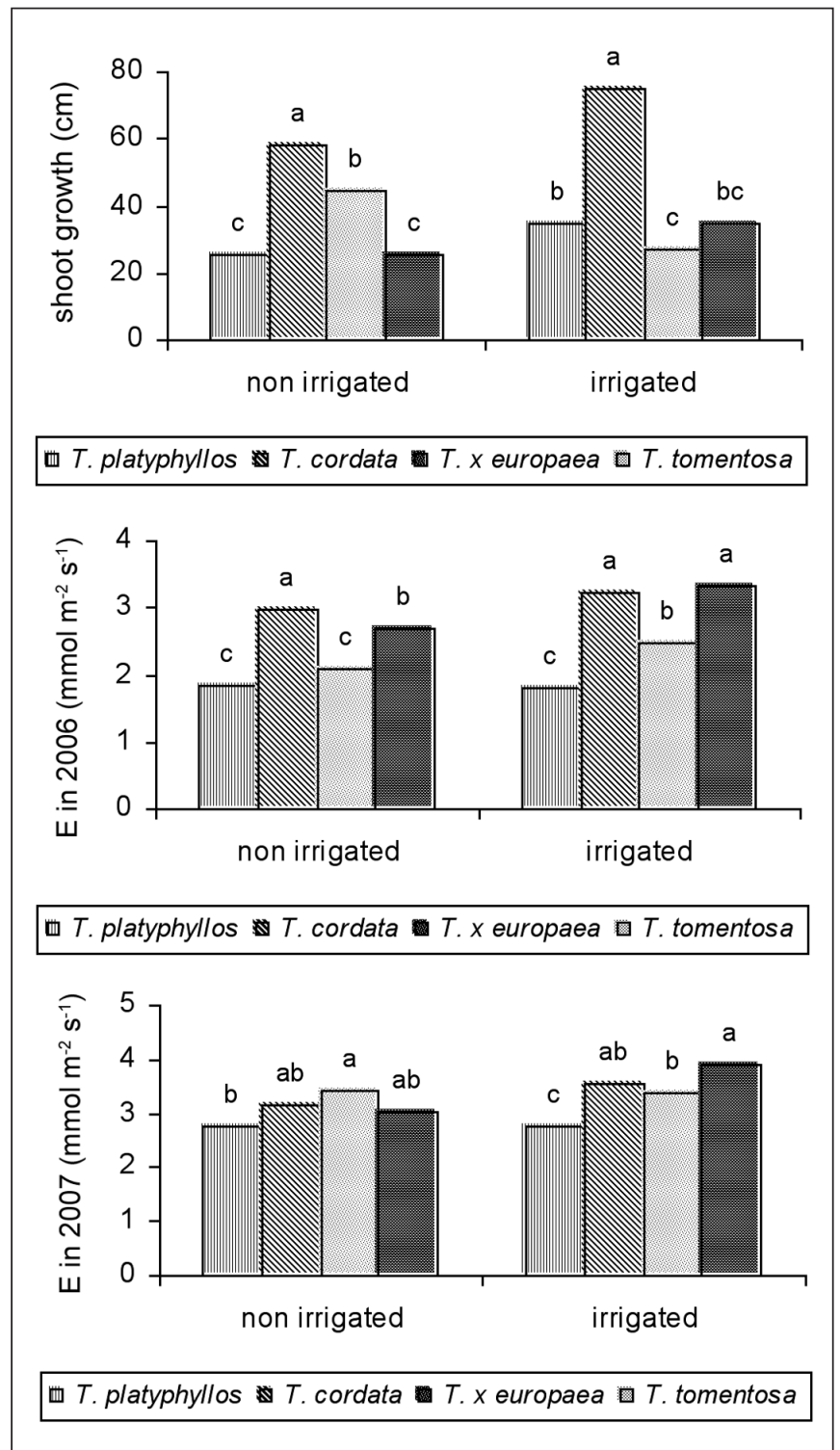

Figure 2. Means separation of those parameters [shoot growth in 2006, transpiration ( $E, \mathrm{mmol} \mathrm{s}^{-1} \mathrm{~m}^{-2}$ ) in 2006 and 2007], which were significantly affected by species $x$ irrigation interaction in Tilia. In this case, Duncan's Multiple Range Test was used to compare the species for each level of irrigation separately. 
Table 1. Shoot extension (cm), Net Photosynthesis (A. $\mu \mathrm{mol} \mathrm{m}^{-2} \mathrm{~s}^{-1}$ ), Transpiration (E. $\mathrm{mmol} \mathrm{m}^{-2} \mathrm{~s}^{-1}$ ), Water Use Efficiency (WUE) and leaf greenness index (Chl, Unit SPAD) in Tilia spp grown under different irrigation regimes. Data are reported as annual means (five sampling dates in 2006, five in 2007), and subjected to two-way ANOVA.

\begin{tabular}{|c|c|c|c|c|c|c|c|c|c|c|}
\hline & \multicolumn{2}{|c|}{$\begin{array}{l}\text { Shoot extension } \\
(\mathrm{cm})\end{array}$} & \multicolumn{2}{|c|}{$\begin{array}{l}\text { A } \\
\left(\mu \mathrm{mol} \mathrm{m} \mathrm{m}^{-2} \mathrm{~s}^{-1}\right)\end{array}$} & \multicolumn{2}{|c|}{$\begin{array}{l}\mathrm{E} \\
\left(\mathrm{mmol} \mathrm{m} \mathrm{m}^{-2} \mathrm{~s}^{-1}\right)\end{array}$} & \multicolumn{2}{|c|}{$\begin{array}{l}\text { WUE } \\
(\mu \mathrm{mol} \mathrm{CO} \\
\left./ \mathrm{mmol} \mathrm{H}_{2} \mathrm{O}\right)\end{array}$} & \multicolumn{2}{|c|}{$\begin{array}{l}\text { Chl } \\
\text { (Unit SPAD) }\end{array}$} \\
\hline & 2006 & 2007 & 2006 & 2007 & 2006 & 2007 & 2006 & 2007 & 2006 & 2007 \\
\hline T. platyphyllos & 30.2 & $45.4 \mathrm{~b}$ & $4.6 \mathrm{~d}$ & $8.1 \mathrm{~b}$ & 1.9 & 2.8 & $2.4 \mathrm{c}$ & 2.9 & $38.6 \mathrm{~d}$ & $43.5 \mathrm{c}$ \\
\hline T. cordata & 66.4 & $50.2 b$ & $9.8 \mathrm{a}$ & $10.3 \mathrm{a}$ & 3.2 & 3.4 & $3.1 \mathrm{a}$ & 3.0 & $49.1 \mathrm{a}$ & $50.8 b$ \\
\hline T. $\times$ europaea & 35.9 & $58.6 \mathrm{a}$ & $5.9 \mathrm{c}$ & $10.5 \mathrm{a}$ & 2.4 & 3.4 & $2.5 \mathrm{c}$ & 3.1 & $43.4 \mathrm{c}$ & $51.9 \mathrm{~b}$ \\
\hline T. tomentosa & 29.9 & $42.9 b$ & $8.2 \mathrm{~b}$ & $10.3 \mathrm{a}$ & 3.0 & 3.4 & $2.8 \mathrm{~b}$ & 3.0 & $46.9 \mathrm{~b}$ & $55 \mathrm{a}$ \\
\hline & & & & & \multicolumn{2}{|c|}{ Irrigation } & & & & \\
\hline Irrigated & 43.1 & 53.4 & 7.3 & 10.1 & 2.7 & 3.4 & 2.7 & 3.0 & 44.0 & 50.3 \\
\hline Nonirrigated & 38.2 & 43.1 & 6.6 & 9.5 & 2.4 & 3.1 & 2.8 & 3.1 & 45.0 & 50.3 \\
\hline$P$ & $*$ & $* *$ & $*$ & N.S. & $* *$ & $* *$ & N.S. & N.S. & N.S. & N.S. \\
\hline & & & & & \multicolumn{2}{|c|}{ Species $\times$ Irrigation } & & & & \\
\hline$P$ & $* *$ & N.S. & N.S. & N.S. & $* *$ & $*$ & N.S. & N.S. & N.S. & N.S. \\
\hline
\end{tabular}

Different letters within the same column indicate statistically differences among species at $P<0.05(*)$ or $P<0.01(* *)$ using Duncan's MRT.

T. tomentosa had lower E than T. cordata when irrigation was withheld, but $\mathrm{E}$ did not differ between the two species in wellwatered conditions. T. platyphyllos and T. $\times$ europaea had lower E than the former two cultivars when irrigation was withheld. Irrigation increased $\mathrm{E}$ in $T . \times$ europaea but not in T. platyphyllos. In 2007, T. cordata had higher E than T. platyphyllos in non irrigated conditions. In the presence of irrigation, T. tomentosa

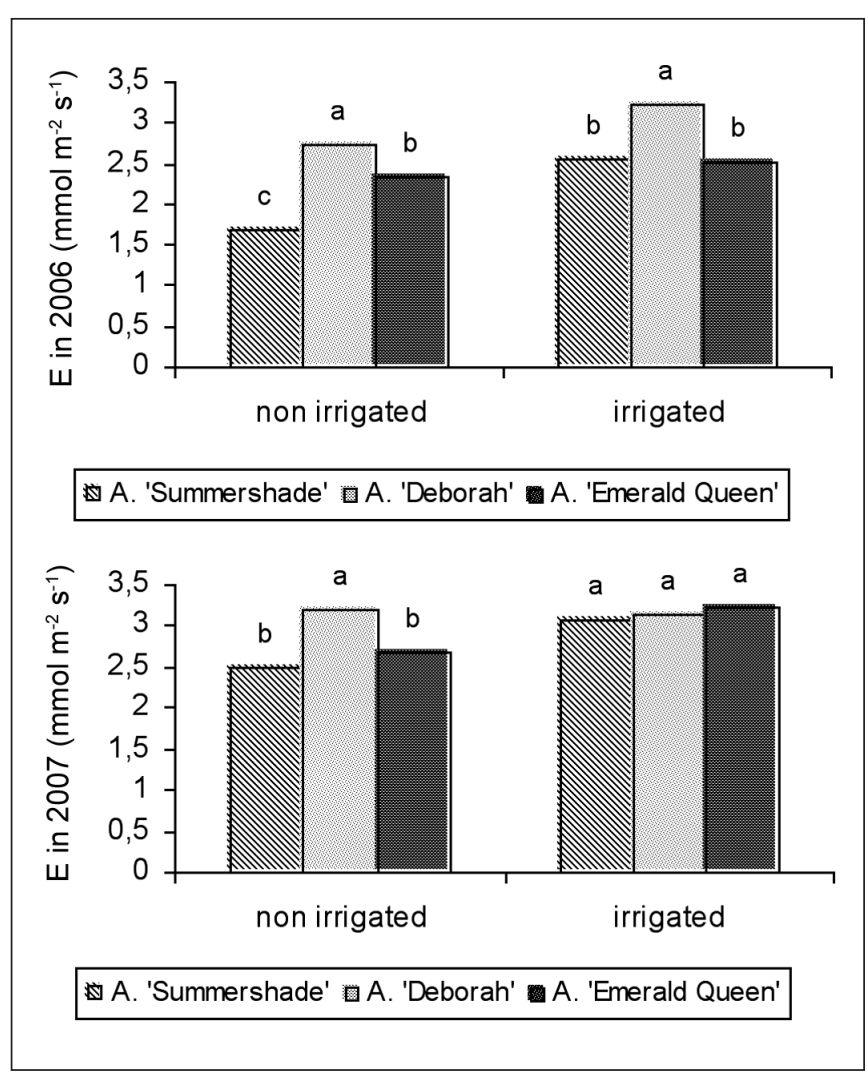

Figure 3. Means separation of those parameters [transpiration $\left(E, \mathrm{mmol} \mathrm{s}^{-1} \mathrm{~m}^{-2}\right)$ in 2006 and 2007], which were significantly affected by cultivar $x$ irrigation interaction in Acer platanoides. In this case, Duncan's Multiple Range Test was used to compare the cultivars for each level of irrigation separately. showed higher $\mathrm{E}$ than $T . \times$ europaea. Among the species studied, the lowest E was measured in T. platyphyllos (Figure 2).

In 2006, Acer platanoides 'Deborah' had higher shoot extension, mean annual A, and leaf chlorophyll content than the other two cultivars (Table 2). No differences were found for WUE and stem diameter (data not shown). In 2007, cultivar 'Deborah' demonstrated faster growth than the other cultivars. There were no differences in A and chlorophyll content among the cultivars in 2007. Irrigation had no effect on shoot extension, trunk diameter growth (data not shown) and chlorophyll content in 2006 (Table 2), but increased mean annual $A$ and $E$ and decreased WUE. In 2007, irrigation reduced shoot growth. In 2007, mean annual A was unaffected by irrigation and mean annual $\mathrm{E}$ was increased. In spite of this, no difference in WUE was found between irrigated and nonirrigated plants. Significant interaction between factors was found for E in 2006 and 2007. In 2006, nonirrigated 'Deborah' maple had higher E than nonirrigated 'Emerald Queen' which, in turn, had higher E than nonirrigated 'Summershade. Where irrigation was applied, 'Deborah' had higher E than the other two cultivars (Figure 3). In 2007, nonirrigated 'Deborah' had higher $\mathrm{E}$ than the other two cultivars. In the presence of irrigation, differences among cultivars disappeared in 2007.

\section{Species/Cultivar Strategies to Cope with Water Stress}

Drought tolerance of the different species was evaluated comparing chlorophyll fluorescence of different individuals of the same species/cultivar grown in well-watered or water-shortage conditions (Angelopulos et al. 1996; Li et al. 2006). Chlorophyll content was not affected by drought treatment in linden species in 2006 and 2007 (Table 3).

$\mathrm{F}_{0}$ is the minimal fluorescence of dark-adapted leaves and this value was used to quantify the detrimental effects of drought on leaf tissues. In T. cordata, T. $\times$ europaea and T. tomentosa, $\mathrm{F}_{0}$ was unaffected by water shortage (Table 3 ). Contrary to the other species, nonirrigated T. platyphyllos had higher $\mathrm{F}_{0}$ on July 12, 2007 if compared to irrigated plants. Increases in $\mathrm{F}_{0}$ have been reported in Olea, Quercus, and some Acer and Fraxinus genotypes in response to water and other environmental and chemical stresses (Angelopulos et al. 1996; Percival et al. 2003; Percival 2005; Percival et al. 
Table 2. Shoot extension (cm), Net Photosynthesis (A. $\mu \mathrm{mol} \mathrm{m} \mathrm{m}^{-2} \mathrm{~s}^{-1}$ ), Transpiration (E. $\mathrm{mmol} \mathrm{m}^{-2} \mathrm{~s}^{-1}$ ), Water Use Efficiency (WUE) and leaf chlorophyll content (Chl, Unit SPAD) in different cultivars of Acer platanoides grown under different irrigation regimes. Data are reported as annual means (five sampling dates in 2006, five in 2007), and subjected to two-way ANOVA.

\begin{tabular}{|c|c|c|c|c|c|c|c|c|c|c|}
\hline & \multicolumn{2}{|c|}{$\begin{array}{l}\text { Shoot extension } \\
(\mathrm{cm})\end{array}$} & \multicolumn{2}{|c|}{$\begin{array}{l}\mathrm{A} \\
\left(\mu \mathrm{mol} \mathrm{m} \mathrm{m}^{-2} \mathrm{~s}^{-1}\right)\end{array}$} & \multicolumn{2}{|c|}{$\begin{array}{l}\mathrm{E} \\
\left(\mathrm{mmol} \mathrm{m}{ }^{-2} \mathrm{~s}^{-1}\right)\end{array}$} & \multicolumn{2}{|c|}{$\begin{array}{l}\text { WUE } \\
(\mu \mathrm{mol} \mathrm{CO} \\
\left./ \mathrm{mmol} \mathrm{H}_{2} \mathrm{O}\right)\end{array}$} & \multicolumn{2}{|c|}{$\begin{array}{l}\text { Chl } \\
\text { (Unit SPAD) }\end{array}$} \\
\hline & 2006 & 2007 & 2006 & 2007 & 2006 & 2007 & 2006 & 2007 & 2006 & 2007 \\
\hline 'Summershade' & $30.1 \mathrm{~b}$ & $48.4 \mathrm{c}$ & $6.3 \mathrm{c}$ & 8.4 & 2.2 & 2.8 & 2.9 & 3.0 & $35.3 \mathrm{c}$ & 42.8 \\
\hline 'Deborah' & $45.7 \mathrm{a}$ & $130.9 \mathrm{a}$ & $8.9 \mathrm{a}$ & 8.5 & 3.0 & 3.1 & 3.0 & 2.7 & $42.8 \mathrm{a}$ & 44.5 \\
\hline 'Emerald Queen' & $23.7 \mathrm{c}$ & $95.9 \mathrm{~b}$ & $7.6 b$ & 8.8 & 2.5 & 2.8 & 3.0 & 3.1 & $39.3 b$ & 43 \\
\hline$P$ & $* *$ & $* *$ & $* *$ & N.S. & $* *$ & $*$ & N.S. & N.S. & $* *$ & N.S. \\
\hline \multicolumn{11}{|c|}{ Irrigation } \\
\hline Irrigated & 32.4 & 83.0 & 7.9 & 8.9 & 2.8 & 3.1 & 2.8 & 2.9 & 39.8 & 43.9 \\
\hline Nonirrigated & 34.4 & 100.3 & 7.3 & 8.2 & 2.3 & 2.8 & 3.2 & 2.9 & 38.6 & 42.9 \\
\hline$P$ & N.S. & $* *$ & $* *$ & N.S. & $* *$ & $* *$ & $*$ & N.S. & N.S. & N.S. \\
\hline \multicolumn{11}{|c|}{ Species $\times$ Irrigation } \\
\hline$P$ & N.S. & N.S. & N.S. & N.S. & * & $*$ & N.S. & N.S. & N.S. & N.S. \\
\hline
\end{tabular}

Different letters within the same column indicate statistically differences among cultivars at $P<0.05(*)$ or $P<0.01$ (**), using Duncan's MRT.

2006). From a theoretical point of view, an increase in $\mathrm{F}_{0}$ can be interpreted as a stress-induced reduction of the rate constant of energy trapping by PSII centers, which result from a physical dissociation of light harvesting complexes from PSII reaction center (Armond et al. 1980; Havaux 1993). Despite the possibility of being influenced by the difference in optical properties between control and stressed leaves (Angelopulos et al. 1996), drought induced variations of $\mathrm{F}_{0}$ were the best predictors $(\mathrm{r}=0.88)$ of grain yield of barley plants exposed to water-stressing conditions ( $\mathrm{Li}$ et al. 2006). Moreover, Percival and Sheriffs (2002), in a study on drought tolerance, found that $\mathrm{F}_{0}$ was an earlier responding parameter than $\mathrm{Fv} / \mathrm{Fm}$ and $\mathrm{Fv} / \mathrm{F}_{0}$ to water stress in some woody perennials.

$\mathrm{Fv} / \mathrm{Fm}$ is a quantitative measure of the maximal photochemical efficiency of PSII (Willits and Peet 2001). Fv/Fm was lower in July and August 2007 in nonirrigated T. platyphyllos if compared to irrigated ones. Fv/Fm was unaffected by drought treatment in T. cordata and T. tomentosa (Table 3). In August 2007, Fv/Fm was higher in nonirrigated T. tomentosa if compared to irrigated plants. Reductions of $\mathrm{Fv} / \mathrm{Fm}$ have been observed in drought-sensitive barley and Fraxinus genotypes in response to water stress ( $\mathrm{Li}$ et al. 2006; Percival et al. 2006).
$\mathrm{Fv} / \mathrm{F}_{0}$ is the maximum primary yield of photochemistry of PSII. $\mathrm{Fv} / \mathrm{F}_{0}$ was not affected by withholding irrigation in Tilia cordata, T. $\times$ europaea; and T. tomentosa. T. platyphyllos showed a significant decline of $\mathrm{Fv} / \mathrm{F}_{0}$ in nonirrigated conditions (Table 3). Similar results were obtained in water-stressed woody perennials and in drought-sensitive barley genotypes (Percival and Sheriffs 2002; Li et al. 2006).

With regard to leaf gas exchange, the different Tilia species responded to water shortage in different ways (Table 4). In T. platyphyllos, which had the lowest photosynthetic potential and WUE, no difference appeared between irrigated and nonirrigated plants for mean annual A, E, and $\mathrm{g}_{\mathrm{s}}$. In T. cordata, water shortage affected only mean annual $\mathrm{E}$ in 2006. In T. $\times$ europaea, water shortage reduced mean annual $\mathrm{E}, \mathrm{g}_{\mathrm{s}}$ and $\mathrm{A}$ in 2006 , but differences were not found in 2007. In particular for this species, a $14 \%$ decrease of $g_{s}$ caused a $16 \%$ and $17 \%$ reduction of $\mathrm{E}$ and $\mathrm{A}$, respectively. The greater decline in A than $\mathrm{g}_{\mathrm{s}}$ observed in 2006 for this species suggests that non-stomatal factors limited photosynthesis of nonirrigated plants, in agreement with that reported by previous research (Davies and Kozlowski 1977; Gazal and Kubiske 2004). In T. tomentosa, water shortage affected leaf gas exchange in both years. Respectively

Table 3. Chlorophyll content and chlorophyll fluorescence $\left(F_{0}, \mathrm{Fv} / \mathrm{Fm}\right.$ and $\left.\mathrm{Fv} / \mathrm{F}_{0}\right)$ in Tilia spp. grown with or without irrigation.

\begin{tabular}{|c|c|c|c|c|c|c|c|c|c|c|c|c|c|c|}
\hline Irrigation & $\begin{array}{l}\text { Chl c } \\
2006\end{array}$ & $\begin{array}{l}\text { ntent } \\
2007\end{array}$ & $\begin{array}{l}\mathrm{F}_{0} \\
\text { Jul/06 }\end{array}$ & Jun/07 & Jul/07 & Aug/07 & $\begin{array}{l}\text { Fv/Fm } \\
\text { Jul/06 }\end{array}$ & Jun/07 & $\mathrm{Jul} / 07$ & Aug/07 & $\begin{array}{l}\mathrm{Fv} / \mathrm{F}_{0} \\
\mathrm{Jul} / 06\end{array}$ & Jun/07 & $\mathrm{Jul} / 07$ & Aug/07 \\
\hline $\begin{array}{l}\text { Irrigated } \\
\text { Nonirrigated } \\
P \\
\end{array}$ & $\begin{array}{l}38.7 \\
38.6 \\
\text { N.S. }\end{array}$ & $\begin{array}{l}44.4 \\
42.6 \\
\text { N.S. }\end{array}$ & $\begin{array}{l}247.5 \\
257.0 \\
\text { N.S. } \\
\end{array}$ & $\begin{array}{l}206.9 \\
205.4 \\
\text { N.S. }\end{array}$ & $\begin{array}{l}220.0 \\
239.0 \\
* *\end{array}$ & $\begin{array}{l}209.3 \\
215.4 \\
\text { N.S. }\end{array}$ & $\begin{array}{l}\text { T. platyl } \\
0.763 \\
0.748 \\
\text { N.S. }\end{array}$ & $\begin{array}{l}\text { yllos } \\
0.774 \\
0.774 \\
\text { N.S. } \\
\end{array}$ & $\begin{array}{l}0.750 \\
0.720 \\
*\end{array}$ & $\begin{array}{l}0.760 \\
0.740 \\
*\end{array}$ & $\begin{array}{l}3.23 \\
3.15 \\
\text { N.S. }\end{array}$ & $\begin{array}{l}3.45 \\
3.45 \\
\text { N.S. }\end{array}$ & $\begin{array}{l}2.99 \\
2.69 \\
* \\
\end{array}$ & $\begin{array}{l}3.15 \\
2.88 \\
*\end{array}$ \\
\hline $\begin{array}{l}\text { Irrigated } \\
\text { Nonirrigated } \\
P \\
\end{array}$ & $\begin{array}{l}42.5 \\
44.3 \\
\text { N.S. }\end{array}$ & $\begin{array}{l}51.5 \\
52.3 \\
\text { N.S. } \\
\end{array}$ & $\begin{array}{l}300.0 \\
275.5 \\
\text { N.S. } \\
\end{array}$ & $\begin{array}{l}224.3 \\
217.4 \\
\text { N.S. } \\
\end{array}$ & $\begin{array}{l}241.8 \\
246.4 \\
\text { N.S. } \\
\end{array}$ & $\begin{array}{l}224.5 \\
222.7 \\
\text { N.S. }\end{array}$ & $\begin{array}{l}\text { T. cordo } \\
0.796 \\
0.793 \\
\text { N.S. } \\
\end{array}$ & $\begin{array}{l}0.778 \\
0.767 \\
\text { N.S. }\end{array}$ & $\begin{array}{l}0.758 \\
0.744 \\
\text { N.S. } \\
\end{array}$ & $\begin{array}{l}0.765 \\
0.759 \\
\text { N.S. } \\
\end{array}$ & $\begin{array}{l}3.95 \\
3.84 \\
\text { N.S. }\end{array}$ & $\begin{array}{l}3.58 \\
3.31 \\
\text { N.S. }\end{array}$ & $\begin{array}{l}3.18 \\
2.93 \\
\text { N.S. }\end{array}$ & $\begin{array}{l}3.29 \\
3.16 \\
\text { N.S. }\end{array}$ \\
\hline $\begin{array}{l}\text { Irrigated } \\
\text { Nonirrigated } \\
P\end{array}$ & $\begin{array}{l}42.5 \\
44.3 \\
\text { N.S. }\end{array}$ & $\begin{array}{l}51.5 \\
52.3 \\
\text { N.S. }\end{array}$ & $\begin{array}{l}285.8 \\
293.0 \\
\text { N.S. }\end{array}$ & $\begin{array}{l}211.5 \\
219.8 \\
\text { N.S. }\end{array}$ & $\begin{array}{l}239.1 \\
239.5 \\
\text { N.S. }\end{array}$ & $\begin{array}{l}219.8 \\
216.4 \\
\text { N.S. }\end{array}$ & $\begin{array}{l}\text { T. } \times \text { eur } \\
0.777 \\
0.785 \\
\text { N.S. }\end{array}$ & $\begin{array}{l}\text { aea } \\
0.776 \\
0.778 \\
\text { N.S. }\end{array}$ & $\begin{array}{l}0.749 \\
0.717 \\
\text { N.S. }\end{array}$ & $\begin{array}{l}0.755 \\
0.744 \\
\text { N.S. }\end{array}$ & $\begin{array}{l}3.59 \\
3.67 \\
\text { N.S. }\end{array}$ & $\begin{array}{l}3.47 \\
3.51 \\
\text { N.S. }\end{array}$ & $\begin{array}{l}3.05 \\
2.62 \\
\text { N.S. }\end{array}$ & $\begin{array}{l}3.11 \\
2.95 \\
\text { N.S. }\end{array}$ \\
\hline $\begin{array}{l}\text { Irrigated } \\
\text { Nonirrigated } \\
P\end{array}$ & $\begin{array}{l}45.5 \\
48.3 \\
\text { N.S. }\end{array}$ & $\begin{array}{l}56.3 \\
53.7 \\
\text { N.S. }\end{array}$ & $\begin{array}{l}322.0 \\
330.8 \\
\text { N.S. }\end{array}$ & $\begin{array}{l}238.0 \\
237.0 \\
\text { N.S. }\end{array}$ & $\begin{array}{l}271.4 \\
270.3 \\
\text { N.S. }\end{array}$ & $\begin{array}{l}253.7 \\
248.7 \\
\text { N.S. }\end{array}$ & $\begin{array}{l}\text { T. tomer } \\
0.797 \\
0.798 \\
\text { N.S. }\end{array}$ & $\begin{array}{l}\text { sa } \\
0.749 \\
0.751 \\
\text { N.S. }\end{array}$ & $\begin{array}{l}0.718 \\
0.736 \\
\text { N.S. }\end{array}$ & $\begin{array}{l}0.733 \\
0.758 \\
*\end{array}$ & $\begin{array}{l}4.00 \\
4.00 \\
\text { N.S. }\end{array}$ & $\begin{array}{l}3.10 \\
3.13 \\
\text { N.S. }\end{array}$ & $\begin{array}{l}2.42 \\
2.84 \\
\text { N.S. }\end{array}$ & $\begin{array}{l}2.80 \\
3.14 \\
\text { N.S. }\end{array}$ \\
\hline
\end{tabular}

$*$ and ** indicate statistical differences at $P<0.05$ (*) or $P<0.01(* *)$ between irrigated and nonirrigated plants of the same species. 
Table 4. Net Photosynthesis (A, $\left.\mu \mathrm{mol} \mathrm{m} \mathrm{m}^{-2} \mathrm{~s}^{-1}\right)$, Transpiration $\left(\mathrm{E}, \mathrm{mmol} \mathrm{m} \mathrm{m}^{-2} \mathrm{~s}^{-1}\right.$ ) and Stomatal conductance $\left(\mathrm{gs}, \mathrm{mmol} \mathrm{m}^{-2} \mathrm{~s}^{-1}\right)$ in Tilia spp., grown with or without irrigation. Data are reported as means of the values obtained from June to September (five sampling dates in 2006, five in 2007), and subjected to analysis of variance.

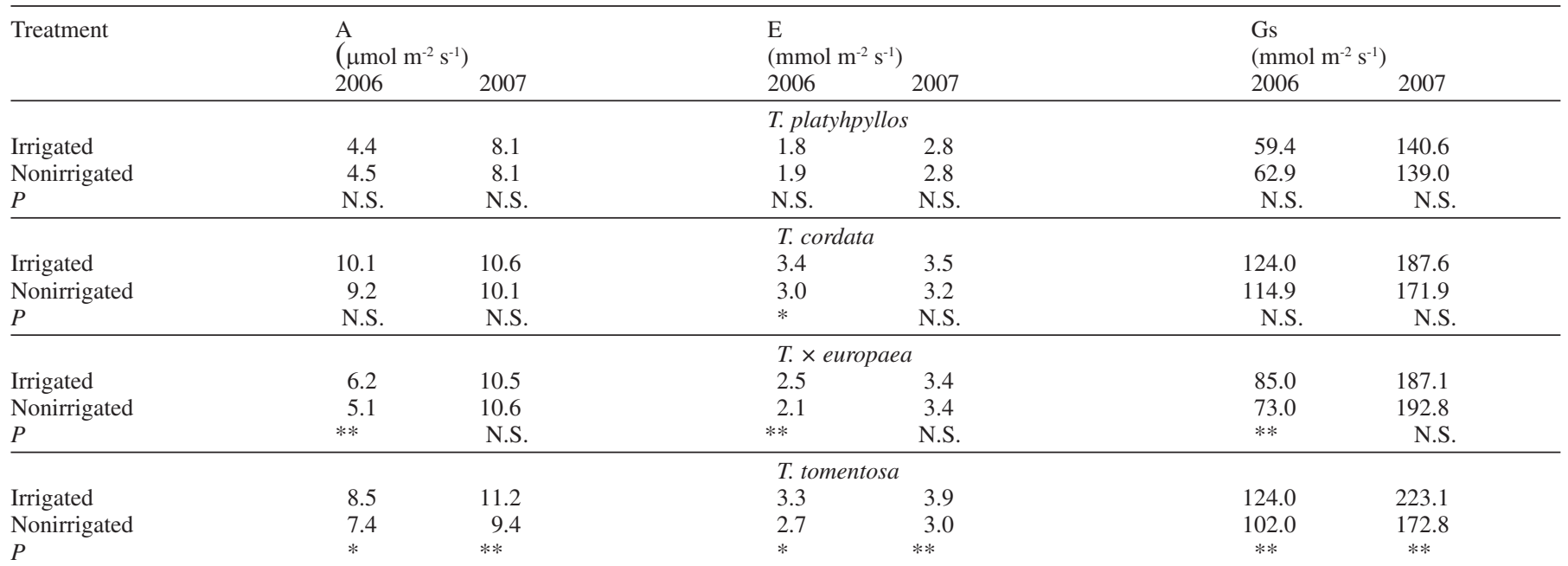

* and $* *$ indicate statistical differences at $P<0.05(*)$ or $P<0.01(* *)$ between irrigated and nonirrigated plants of the same species.

Table 5. Chlorophyll content and chlorophyll fluorescence $\left(\mathrm{F}_{0}, \mathrm{Fv} / \mathrm{Fm}\right.$ and $\left.\mathrm{Fv} / \mathrm{F}_{0}\right)$ in different cultivars of Acer platanoides grown with or without irrigation.

\begin{tabular}{|c|c|c|c|c|c|c|c|c|c|c|c|c|c|c|}
\hline \multirow[t]{2}{*}{ Irrigation } & \multicolumn{2}{|c|}{ Chl content } & \multirow{2}{*}{$\begin{array}{l}\mathrm{F}_{0} \\
\text { Jul/06 }\end{array}$} & \multirow[b]{2}{*}{ Jun/07 } & \multirow[b]{2}{*}{$\mathrm{Jul} / 07$} & \multirow[b]{2}{*}{ Aug/07 } & \multirow{2}{*}{$\begin{array}{l}\text { Fv/Fm } \\
\text { Jul/06 }\end{array}$} & \multirow[b]{2}{*}{ Jun/07 } & \multirow[b]{2}{*}{$\mathrm{Jul} / 07$} & \multirow[b]{2}{*}{ Aug/07 } & \multirow{2}{*}{$\begin{array}{l}\mathrm{Fv} / \mathrm{F}_{0} \\
\mathrm{Jul} / 06\end{array}$} & \multirow[b]{2}{*}{ Jun/07 } & \multirow[b]{2}{*}{$\mathrm{Jul} / 07$} & \multirow[b]{2}{*}{ Aug/07 } \\
\hline & 2006 & 2007 & & & & & & & & & & & & \\
\hline & & & & & & 'Summer & & & & & & & & \\
\hline Irrigated & 35.3 & 43.0 & 238.0 & 243.7 & 257.0 & 225.5 & 0.775 & 0.775 & 0.738 & 0.736 & 3.50 & 3.47 & 2.83 & 2.83 \\
\hline \multirow[t]{2}{*}{$P$} & N.S. & N.S. & $*$ & N.S. & $*$ & $*$ & N.S. & N.S. & N.S. & N.S. & N.S. & N.S. & $*$ & $*$ \\
\hline & & & & & & 'Deborah & & & & & & & & \\
\hline Irrigated & 44.6 & 45.9 & 237.0 & 244.6 & 266.7 & 235.7 & 0.782 & 0.764 & 0.733 & 0.732 & 3.70 & 3.24 & 2.80 & 2.75 \\
\hline Nonirrigated & 41.1 & 43.6 & 235.4 & 239.8 & 266.6 & 236.4 & 0.784 & 0.765 & 0.71 & 0.713 & 3.60 & 3.30 & 2.62 & 2.68 \\
\hline \multirow[t]{2}{*}{$P$} & $*$ & N.S. & N.S. & N.S. & N.S. & N.S. & N.S. & N.S. & N.S. & N.S. & N.S. & N.S. & N.S. & N.S. \\
\hline & & & & & & 'Emerald & en' & & & & & & & \\
\hline Irrigated & 39.3 & 43.4 & 231.8 & 222.3 & 269.0 & 228.9 & 0.779 & 0.774 & 0.722 & 0.731 & 3.60 & 3.46 & 2.52 & 2.73 \\
\hline Nonirrigated & 39.4 & 42.6 & 236.2 & 232.4 & 261.2 & 241.9 & 0.778 & 0.768 & 0.708 & 0.713 & 3.60 & 3.33 & 2.62 & 2.64 \\
\hline$P$ & N.S. & N.S. & N.S. & N.S. & N.S. & N.S. & N.S. & N.S. & N.S. & N.S. & N.S. & N.S. & N.S. & N.S. \\
\hline
\end{tabular}

* and ** indicate statistical differences at $P<0.05(*)$ or $P<0.01(* *)$ between irrigated and nonirrigated plants of the same cultivar.

Table 6. Net Photosynthesis (A, $\left.\mu \mathrm{mol} \mathrm{m} \mathrm{m}^{-2} \mathrm{~s}^{-1}\right)$, Transpiration $\left(E, \mathrm{mmol} \mathrm{m}^{-2} \mathrm{~s}^{-1}\right.$ ) and Stomatal Conductance $\left(\mathrm{gs}, \mathrm{mmol} \mathrm{m}^{-2} \mathrm{~s}^{-1}\right)$ in different cultivars of Acer platanoides, grown with or without irrigation. Data are reported as means of the values obtained from June to September (five sampling dates in 2006 , five in 2007), and subjected to analysis of variance.

\begin{tabular}{|c|c|c|c|c|c|c|}
\hline \multirow[t]{2}{*}{ Treatment } & \multicolumn{2}{|l|}{ A } & \multicolumn{2}{|l|}{$\mathrm{E}$} & \multicolumn{2}{|c|}{$\left(\mathrm{mmol} \mathrm{m} \mathrm{m}^{-2} \mathrm{~s}^{-1}\right)$} \\
\hline & 2006 & 2007 & 2006 & 2007 & 2006 & 2007 \\
\hline & & & \multicolumn{4}{|c|}{ 'Summershade' } \\
\hline Irrigated & 6.6 & 8.9 & 2.6 & 3.1 & 118.2 & 175.2 \\
\hline Nonirrigated & 6.1 & 7.8 & 1.9 & 2.5 & 93.0 & 148.9 \\
\hline$P$ & N.S. & N.S. & $* *$ & $* *$ & $* *$ & N.S. \\
\hline Irrigated & 9.5 & 9.0 & 3.2 & 3.1 & 163.4 & 179.0 \\
\hline Nonirrigated & 8.4 & 8.6 & 2.7 & 3.2 & 147.0 & 194.3 \\
\hline \multirow[t]{2}{*}{$P$} & $* *$ & N.S. & $* *$ & N.S. & $* *$ & N.S. \\
\hline & & & \multicolumn{4}{|c|}{ 'Emerald Queen' } \\
\hline Irrigated & 7.8 & 8.9 & 2.6 & 3.0 & 124.7 & 174.5 \\
\hline Nonirrigated & 7.5 & 8.1 & 2.4 & 2.7 & 117.5 & 124.7 \\
\hline$P$ & N.S. & N.S. & N.S. & $*$ & N.S. & N.S. \\
\hline
\end{tabular}

* and ** indicate statistical differences at $P<0.05(*)$ or $P<0.01(* *)$ between irrigated and nonirrigated plants of the same cultivar. 
for 2006 and 2007, a reduction in $\mathrm{g}_{\mathrm{s}}$ of $17 \%$ and $22 \%$ decreased E by $19 \%$ and $22 \%$, and reduced $\mathrm{A}$ by $12 \%$ and $16 \%$. WUE was never affected by water regime in Tilia species (data not shown).

Chlorophyll content of maple cultivars was unaffected by irrigation except for 'Deborah' in 2006, when irrigated plants had higher leaf chlorophyll content than nonirrigated plants (Table 5).

$\mathrm{F}_{0} \mathrm{Fv} / \mathrm{Fm}$, and $\mathrm{Fv} / \mathrm{F}_{0}$ were unaffected by water regime in cultivars 'Deborah' and 'Emerald Queen'. In July and August 2007, nonirrigated 'Summershade' had higher $\mathrm{F}_{0}$ and lower $\mathrm{Fv} / \mathrm{F}_{0}$ than in the irrigated treatment, although no difference was found for Fv/Fm. Considering the different maple cultivars, water shortage never affected mean annual A, except for 'Deborah' in 2006, when irrigated plants fixed $11 \%$ more atmospheric carbon than nonirrigated ones (Table 6). No difference was found in 2007.

If compared to irrigated plants, nonirrigated maples had lower mean annual E in both years (cv. 'Summershade'); only in 2006

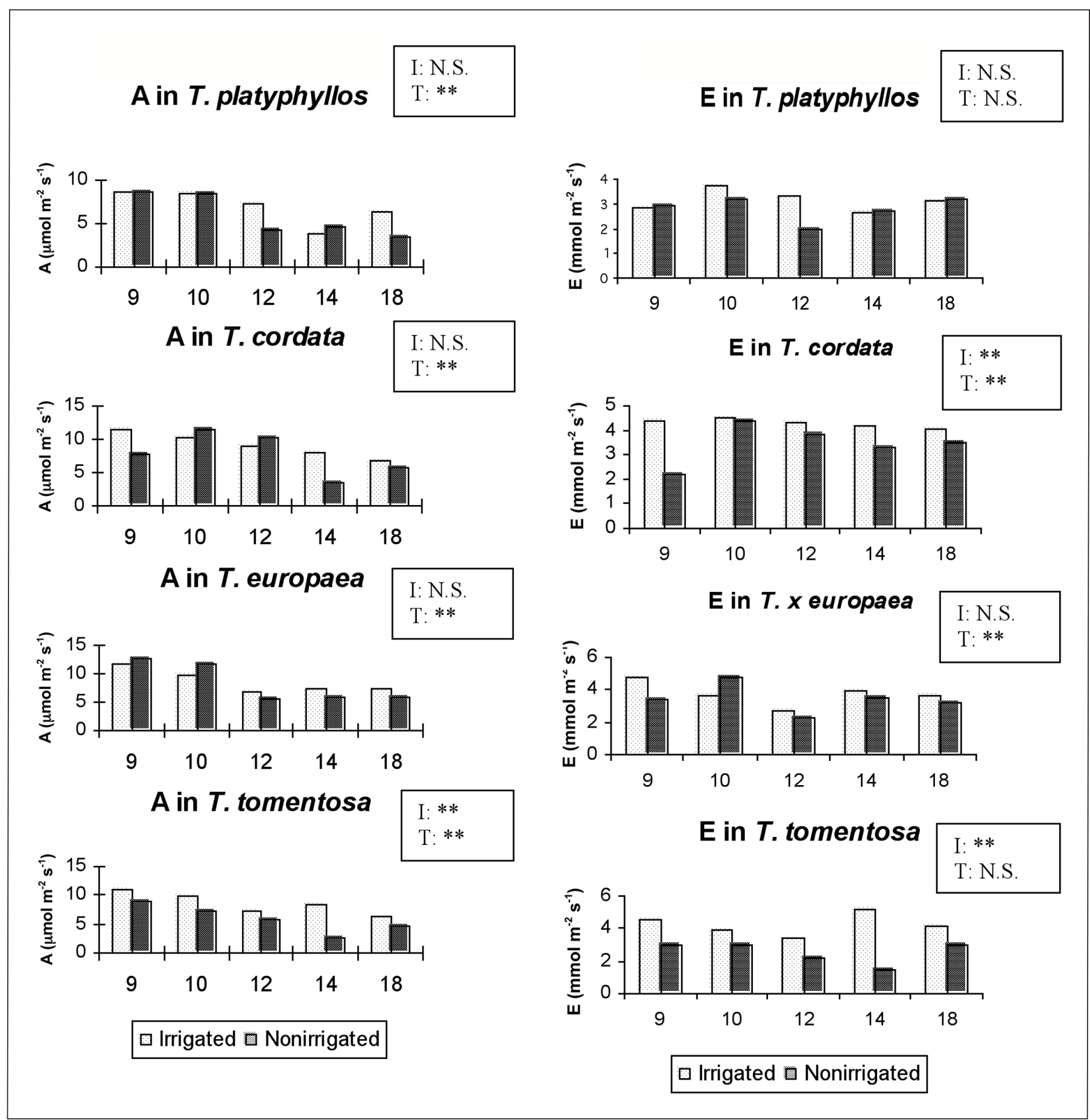

Figure 4. Daily trend of net assimilation $\left(A, \mu \mathrm{mol} \mathrm{m}^{-2} \mathrm{~s}^{-1}\right)$ and transpiration $\left(E, \mathrm{mmol} \mathrm{m}^{-2} \mathrm{~s}^{-1}\right)$ in the four linden species grown in well watered and water shortage conditions. Data are the average between the two sampling dates (July 20 and 27, 2007). Single asterisk (*) and double-asterisks $\left(^{* *}\right)$ in the right-top corner of each graph indicate statistically differences at $P<0.05\left(^{*}\right)$ or $P<0.01\left({ }^{* *}\right)$, using ANOVA test for the factors I (irrigation) and T (time). 
A in Acer 'Summershade'
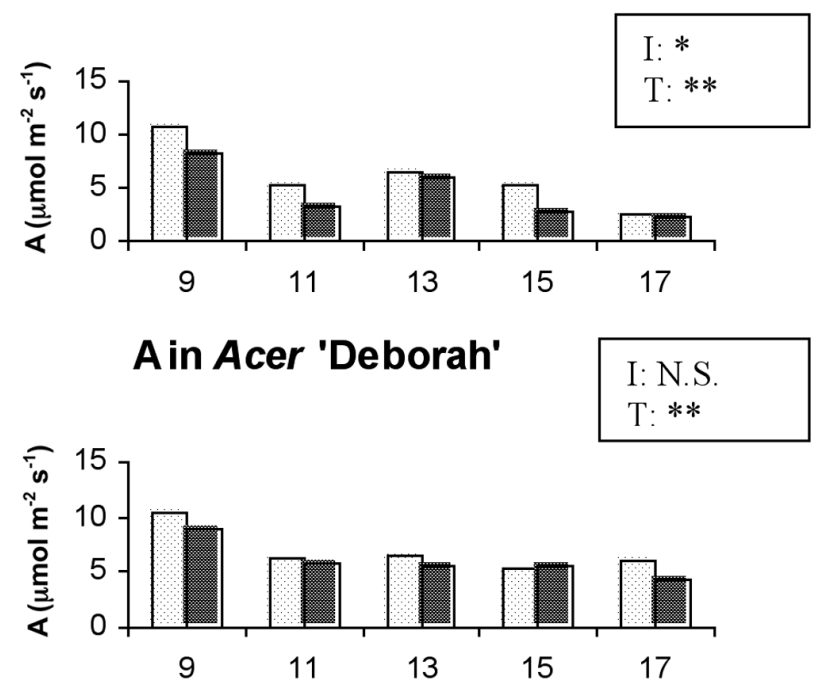

A in Acer 'Emerald Queen'

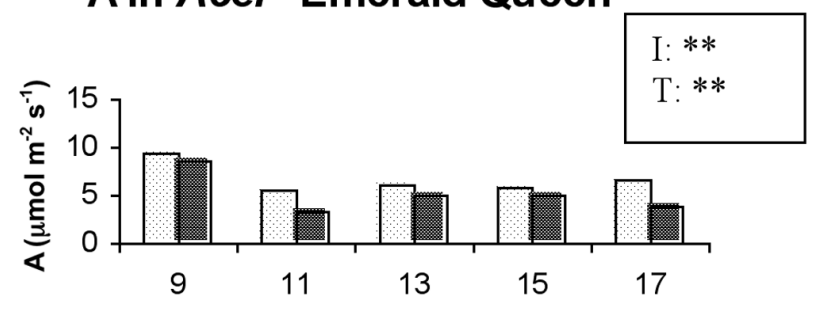

$\square$ Irrigated Nonirrigated
E in Acer 'Summershade'
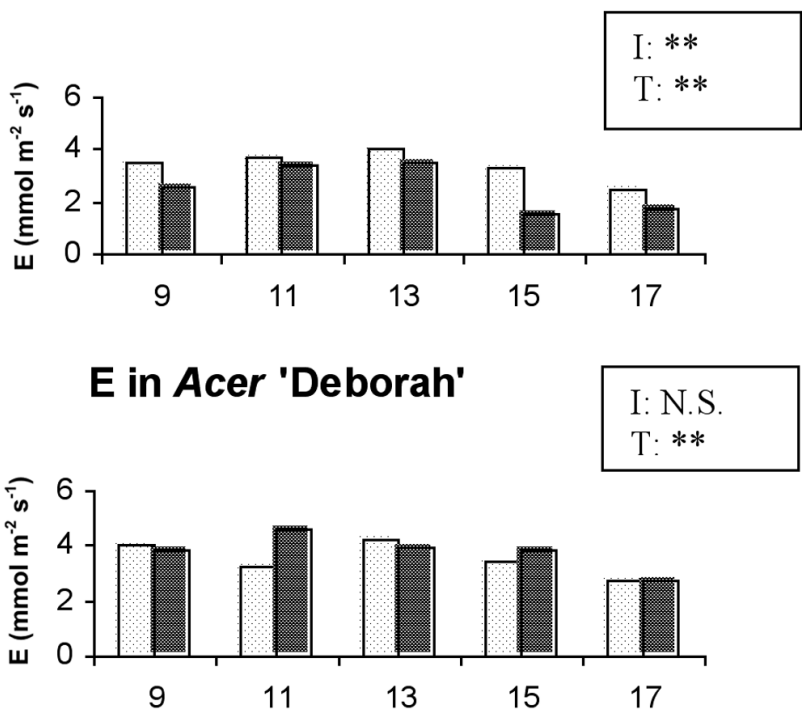

E in Acer 'Emerald Queen'

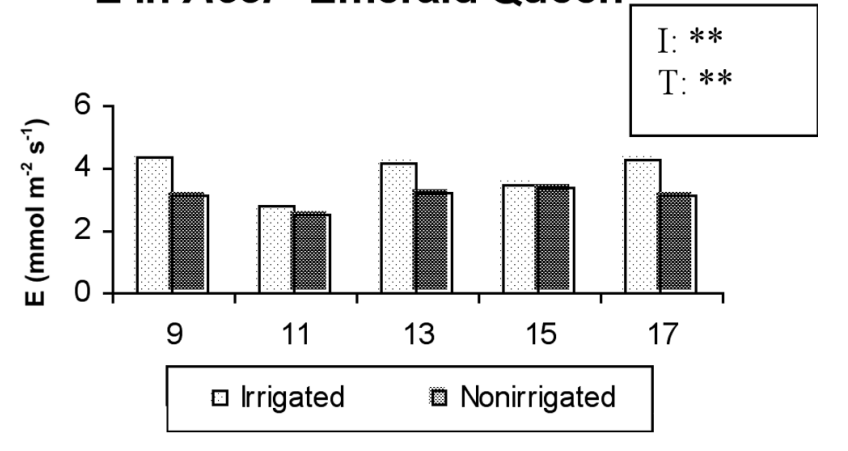

Figure 5. Daily trend of net assimilation $\left(A, \mu \mathrm{mol} \mathrm{m} \mathrm{m}^{-2} \mathrm{~s}^{-1}\right)$ and transpiration $\left(E, \mathrm{mmol} \mathrm{m}^{-2} \mathrm{~s}^{-1}\right)$ in the three Norway maple cultivars grown in well watered and water shortage conditions. Data are the average between the two sampling dates (July 20 and 27, 2007). Single asterisk $\left(^{*}\right)$ and double-asterisks $\left(^{* *}\right)$ in the right-top corner of each graph indicate statistically differences at $P<0.05\left(^{*}\right)$ or $P<0.01\left(^{* *}\right)$, using ANOVA test for the factors I (irrigation) and T (time).

(cv. 'Deborah') or only in 2007 (cv. 'Emerald Queen'). g was affected by water regime only in 2006 in the cultivars 'Summershade' and 'Deborah'.

Daily gas exchage trend, measured on July 20 and 27, 2007, differed among species/cultivar (Figure 4; Figure 5). A was not affected by water regime except for T. tomentosa, which showed higher carbon assimilation under irrigated conditions (Figure 4). A was affected by sampling time in all linden species, generally reaching the minimum between 12.00 and $14.00 \mathrm{~h}$. Some recovery was observed at $18.00 \mathrm{~h}$ only in irrigated T. platyphyllos and nonirrigated $T$. cordata and T. tomentosa. E was not influenced by water conditions in T. platyphyllos and T. × europaea. Irrigated T. tomentos $a$ and $T$. cordata transpired more water than nonirrigated plants of the same species, but in littleleaf linden significant differences between irrigation treatments appeared only at $9.00 \mathrm{~h}$. In irrigated T. tomentosa, E remained fairly constant during the day, while in nonirrigated silver linden a significant drop in E occurred at 12.00 $\mathrm{h}$ and $14.00 \mathrm{~h}$. In this species, E recovered completely at $18.00 \mathrm{~h}$.
In Acer platanoides 'Summershade' and 'Emerald Queen', irrigation affected gas exchange, with irrigated plants having higher $\mathrm{A}$ and $\mathrm{E}$ than nonirrigated plants for the entire day (Figure 3). On the contrary, in Acer platanoides 'Deborah' irrigation treatment had no influence on A and E throughout the day. Sampling time influenced $\mathrm{A}$ and $\mathrm{E}$ in all cultivars (Figure 5). A reached its maximum at $9.00 \mathrm{~h}$ in all cultivars. In Acer platanoides, 'Summershade' and 'Deborah', A kept declining during the day, reaching its minimum at $17.00 \mathrm{~h}$. In Acer platanoides, 'Emerald Queen' a drop in A was observed at $11.00 \mathrm{~h}$, then there was a subsequent recovery until $15.00 \mathrm{~h}$ and a final drop at $17.00 \mathrm{~h}$. E was also influenced by sampling time in all the cultivars. In Acer platanoides, 'Summershade' the increase in E observed from $9.00 \mathrm{~h}$ to 13.00 $\mathrm{h}$ was followed by a drop in the afternoon. This drop was particularly evident in nonirrigated Acer platanoides 'Summershade'. No clear trend was observed in the 'Emerald Queen' cultivar. 


\section{CONCLUSION}

Norway maple establishment was promoted by irrigation for two years after transplant. After this period, irrigation is probably not needed anymore. Linden establishment was promoted by irrigation also in the third growing season after transplant, while more research is needed to determine for how long Tilia should be irrigated after planting in the landscape. Only in T. platyphyllos and Acer 'Summershade' did water shortage cause a significant increase in $\mathrm{F}_{0}$ and decline in the primary yield of PSII. In T. platyphyllos, Fv/Fm was significantly decreased by drought. These effects on chlorophyll fluorescence parameters have been related to the occurrence of water or other environmental and chemical stresses. On this basis, these two species were considered the least tolerant to water stress during the establishment phase. Different responses to water shortage were found in the different species and cultivars. T. platyphyllos had lower gas exchange than the other species, even in well-watered conditions and stomatal conductance, carbon assimilation and transpiration were unaffected by water shortage. This strategy was also found in beech seedlings from dry (rainfall $580-680 \mathrm{~mm} /$ year) provenances (Pueke et al. 2002), but in the case of linden, it failed to prevent disruption of PSII under nonirrigated conditions. T. cordata, T. $\times$ europaea, Acer 'Deborah' and 'Emerald Queen' showed, in 2007, higher gas exchange which was little affected by water shortage. This "water spending" strategy may depend on a better access to soil water thanks to a more developed root system (Levitt 1972; Mediavilla and Escudero 2004). This is also confirmed by the fact that before full establishment (2006, two years from transplant) effects of water shortage on leaf gas exchange were observed-especially in T. $\times$ europaea and Acer platanoides 'Deborah'. T. tomentosashowed high gas exchange, but, in response to water shortage, stomatal conductance and transpiration were reduced. A similar strategy was found on Quercus coccinea and classified as "drought avoidance based on water saving" by Sakcali and Ozturk (2004).

The results obtained in this experiment may be a useful tool for species/cultivar selection for urban forestry. Among lindens, T. tomentosa seems particularly adapted to those situations where root development and root access to water is limited by small planting pits (e.g., street trees). T. cordata, which showed the highest gas exchange and water use efficiency in the year following transplant, seems well suited to perform well where access to underground water is not restricted. Differences among Norway maple cultivars seem smaller than those observed among lindens (no significant differences in Fv/Fm). Regardless, in the establishment phase, A. platanoides 'Deborah' and 'Emerald Queen' seem better performers than Acer 'Summershade'.

Acknowledgments. This work has been undertaken as a research project with the title "Tecniche eco-compatibili di gestione del vivaismo e del verde ornamentale" financed by Regione Lombardia - Agricultural Department, according to the Plan of Research and Development 2004.

\section{LITERATURE CITED}

Abrams, M.D., and M.E. Kubiske. 1990. Photosynthesis and water relations during drought in Acer rubrum L. genotypes from contrasting sites in central Pennsylvania. Functional Ecology 4:727-733.

Akbari, H. 2002. Shade trees reduce building energy use and $\mathrm{CO}_{2}$ emissions from power plants. Environmental Pollution 116:S119-S126.
Angelopulos, K., B. Dichio, and C. Xiloyannis. 1996. Inhibition of photosynthesis in olive trees (Olea europaea L.) during water stress and rewatering. Journal of Experimental Botany 47(301):1093-1100.

Armond, P.A., O. Björkman, and L.A. Staehelin. 1980. Dissociation of supramolecular complexes in chloroplast membranes: a manifestation of heat damage to the photosynthetic apparatus. Biochemica and Biophysica Acta 601:433-442.

Brack, C.L. 2002. Pollution mitigation and carbon sequestration by an urban forest. Environmental Pollution 116:S195-S200.

Chew, V. 1976. Uses and abuses of Duncan's Multiple Range Test. Proc. Fla. State Hort. Soc. 89:251-253.

Daugherty, R. 2002. Untitled. Front Range Community College, Westminister, CO, www.timberlinelandscaping.com/Rev'dPlants-FRCCTL/TreesPDFs.

Davies, W.J., and T.T. Kozlowski. 1977. Variations among woody plants in stomatal conductance and photosynthesis during and after growth. Plant and Soil 46:435-444.

Elmendorf, W. 2008. The importance of trees and nature in community: a review of the relative literature. Arboriculture \& Urban Forestry 34(3):152-156.

Escobedo, F.J., J.E. Wagner, D.J. Nowak, C.L. De la Maza, M. Rodriguez and D.E. Crane. 2008. Analyzing the cost-effectiveness of Santiago, Chile's policy of using urban forest to improve air quality. Journal of Environmental Management 86:148-157.

Ferrini, F., A. Fini, P. Frangi, and G. Amoroso. 2008. Mulching of ornamental trees: effects on growth and physiology. Arboriculture \& Urban Forestry 34(3): 157-162.

Fini, A., and F. Ferrini. 2007. Influenza dell'ambiente urbano sulla fisiologia e la crescita degli alberi. Italus Hortus 14(1):9-24.

Fini, A., G.B. Mattii, and F. Ferrini. 2008. Physiological responses to different irrigation regimes for shade trees grown in container. Advances in Horticultural Sciences 22(1):13-20.

Fisher, G., M. Shah, H. van Veultuizen, and F.O. Nachtergaele. 2001. Global agro-ecological assessment for agriculture in the 21st Century. Laxenburg, Austria: IIASA and FAO.

Gazal R.M., and M.E. Kubiske. 2004. Influence of initial root lenght on physiological responses of cherrybark oak and Schumard oak seedlings to field drought conditions. Forest Ecology and Management 189:295-305.

Gilbertson, P., and A.D. Bradshaw. 1985. Tree survival in the cities: the extent and nature of the problem. Arboricultural Journal 9:131-142.

Havaux, M. 1993. Characterization of thermal damage to photosynthetic electron transport system in potato leaves. Plant Science 94:19-33.

Kaushal, P., and G. Aussenac. 1989. Transplant shock in corsican pine and cedar of atlas seedlings: internal water deficits, growth and root regeneration. Forest Ecology and Management 27:29-40.

Lazár, D. 2006. The polyphasic chlorophyll a fluorescence rise measured under high intensity of exciting light. Functional Plant Biology 33:9-30.

Levitt, J. 1972. Responses of plants to environmental stresses. Academic Press, New York, 697 pp.

Li, R., P. Guo, M. Baum, S. Grando, and S. Ceccarelli. 2006. Evaluation of chlorophyll content and fluorescence parameters as indicators of drought tolerance in barley. Agricultural Sciences in China 5(10):751-757.

Maxwell, K., and G.N. Johnson. 2000. Chlorophyll fluorescence - a practical guide. Journal of Experimental Botany 51:659-668.

McPherson, E.G. 2003. A benefit-cost analysis of ten street tree species in Modesto, California, U.S. Journal of Arboriculture 29(1):1-8. 
Mediavilla, S., and A. Escudero. 2004. Stomatal responses to drought of mature trees and seedlings of two co-occurring Mediterranean oaks. Forest Ecology and Management 187:281-294.

Miller, R.H., and R.W. Miller. 1991. Planting survival of selected street tree taxa. Journal of Arboriculture 17(7):185-191.

Montague, T., R. Kjelgren, and L. Rupp. 2000. Gas exchange and growth of two transplanted, field grown tree species in an arid climate. HortScience 35:763-768.

Nowak, D.J., J.R. McBride, and R.A. Beatty. 1990. Newly planted street tree growth and mortality. Journal of Arboriculture 16(5):124-129.

Nowak, D.J., R. Hoehn, and D.E. Crane, 2007. Oxygen production by urban trees in the United States. Arboriculture and Urban Forestry 33(3):220-226.

Pardossi, A., L. Incrocci, and P. Marzialetti. 2004. La razionalizzazione dell'irrigazione nel florovivaismo: una sintesi. In ARSIA (Eds.), Uso razionale delle risorse nel florovivaismo: l'acqua, Florence, Italy, $285 \mathrm{pp}$.

Pauleit, S., N. Jones, G. Garcia-Martin, J.L. Garcia-Valdecantos, L.M. Rivière, L. Vidal-Beaudet, M. Bodson, and T.B. Raundrup. 2002. Tree establishment practice in towns and cities - Results from a European survey. Urban Forestry \& Urban Greening 1:83-96.

Percival, G.C., and G.A. Fraser. 2001. Measurement of the salinity and freezing tolerance of Crataegus genotypes using chlorophyll fluorescence. Journal of Arboriculture 27(5):233-245.

Percival, G.C., and C.N. Sheriffs. 2002. Identification of drought-tolerance woody perennials using chlorophyll fluorescence. Journal of Arboriculture 28(5):215-223.

Percival, G.C., G.A. Fraser, and G. Oxenham. 2003. Foliar salt tolerance of Acer genotypes using chlorophyll fluorescence. Journal of Arboriculture 29(2):61-65.

Percival, G.C. 2005. The use of chlorophyll fluorescence to identify chemical and environmental stress in leaf tissue of three oak (Quercus) species. Journal of Arboriculture 31(5):215-227.

Percival, G.C., I.P. Keary, and S. AL-Habsi. 2006. An assessment of the drought tolerance of Fraxinus genotype for urban landscape planting. Urban Forestry \& Urban Greening 5(1):17-27.

Percival, G.C., I.P. Keary, and K. Noviss. 2008. The potential of a chlorophyll content SPAD meter to quantify nutrient stress in foliar tissue of sycamore (Acer pseudoplatanus), English oak (Quercus robur), and european beech (Fagus sylvatica). Arboriculture \& Urban Forestry 34(2):89-100.

Pueke A.D., C. Schraml, W. Hartung, and H. Rennenberg. 2002. Identification of drougth-sensitive beech ecotypes by physiological paramenters. New Phytologist 154:373-387.

Sakcali M.S., and M. Ozturk. 2004. Eco-physiological behaviour of some Mediterranean plants as suitable candidates for reclamation of degraded areas. Journal of Arid Environments 57:1-13.

Scheiber, S.M., E.F. Gilman, M. Paz, and K.A. Moore. 2007. Irrigation affects landscape establishment of Burford holly, pittosporum and sweet viburnum. HortScience 42(2):344-348.
UNEP/IUC. 1999. United Nations Framework Convention on Climate Change Information kit. Climate Change information sheet. Williams M. (Eds.), Geneva, Chatelaine, Switzerland, 40 pp.

Willits D.H., and M.M. Peet. 2001. Using chlorophyll fluorescence to model leaf photosynthesis in greenhouse pepper and tomato. Acta Horticulturae 507:311-315.

Whitlow, T.H., N.L. Bassuk, and D.L. Reichert. 1992. A 3-year study of water relations of urban street trees. Journal of Applied Ecology 29(2):436-450.

Yamada, M., D. Hidaka, and H. Fukamachi. 1996. Heat tolerance in leaves of tropical fruit crops as measured by chlorophyll fluorescence. Scientia Horticulturae 67:39-48.

Zwack, J.A., W.R. Graves, and A.M. Townsend. 1998. Leaf water relations and plant development of three Freeman maple cultivars subjected to drought. Journal of American Society of Horticulture Science 123(3):371-375.

\section{Alessio Fini}

Dipartimento di Ortoflorofrutticoltura

Viale delle Idee, 30

Sesto Fiorentino (FI), 50019 Italy

alessio.fini@unifi.it

Francesco Ferrini (corresponding author)

Dipartimento di Ortoflorofrutticoltura

Viale delle Idee, 30

Sesto Fiorentino (FI), 50019 Italy

francesco.ferrini@unifi.it

Piero Frangi

Fondazione Minoprio

Centro Mirt

Viale Raimondi, 54

Vertemate con Minoprio (CO), 22070 Italy

frangi@fondazioneminoprio.it

Gabriele Amoroso

Fondazione Minoprio

Centro Mirt

Viale Raimondi, 54

Vertemate con Minoprio (CO), 22070 Italy g.amoroso@fondazioneminoprio.it

Riccardo Piatti

Fondazione Minoprio

Centro Mirt

Viale Raimondi, 54

Vertemate con Minoprio (CO), 22070 Italy

r.piatti@fondazioneminoprio.it 
Zusammenfassung. Das Ziel dieser Arbeit war, die Trockenheitsresistenz von verschiedenen Lindenarten und verschiedenen Ahorn-Kultivaren während der Anpflanzphase zu untersuchen und den Bewässerungseffekt auf ihr Wachstum und Physiologie zu bewerten. Im Winter 2004/05 wurden 168 Bäume mit Stammumfang von $8-10 \mathrm{~cm}$ (Tilia platyphyllos, $T$. cordata, T. $\times$ europaea, T. tomentosa, Acer platanoides 'Summershade', A. platanoides 'Deborah', und A. platanoides 'Emerald Queen'im Feld ausgepflanzt. 84 Pflanzen wurden mit einer Tröpfchenbewässerung (41/h) bewässert und 84 erhielten kein Wasser. Höhe, Stammdurchmesser und Trieblängen wurden am Ende der Wachstumsperiode 2005, 2006 und 2007 gemessen. Blattgasaustausch und Chlorophyllfluoreszenz wurden monatlich während der Wachstumsperiode in 2006 und 2007 gemessen. Der Blattgrün-Index-Gehalt wurde in 2006 und 2007 gemessen. Die Resultate zeigen, dass $T$. tomentosa and $T$. cordata mehr stressresistent sind während der Anwachsphase als T. platyphyllos, während Acer platanoides 'Summershade' weniger stressresistent während der Anwachsphase ist als die Kultivare Emerald Queen' and 'Deborah'.
Resumen. La intención de este trabajo fue investigar la tolerancia a la sequía de especies de Tilia y de diferentes cultivares de Acer platanoides crecidos durante la fase de establecimiento, y evaluar el efecto del riego en su fisiología y crecimiento. En el invierno de 2004-2005, 168 árboles [8-10 cm (3-4 pulg) circunferencia] de Tilia platyphyllos, T. cordata, T. $\times$ europaea, T. tomentosa, Acer platanoides 'Summershade', A. platanoides 'Deborah', y A. platanoides 'Emerald Queen' fueron plantados en el campo. Ochenta y cuatro plantas fueron regadas con sistema por goteo (4 l/h) y otros 84 no lo fueron. Se midió altura, diámetro del tronco y elongación de los brotes al final de la estación de crecimiento en 2005, 2006 y 2007. El intercambio de gases en las hojas y la fluorescencia de clorofila fueron medidas mensualmente durante las estaciones de crecimiento de 2006 y 2007. El índice de vigor contenido en las hojas fue medido en 2006 y 2007. Los resultados indican que $T$. tomentosa y $T$. cordata son más tolerantes a la sequía durante el establecimiento que T. platyphyllos, mientras que Acer platanoides 'Summershade' es menos tolerante a la sequía durante el establecimiento que los cultivares 'Emerald Queen' y 'Deborah'. 